\title{
ARTERIOVENOUS MALFORMATION IN THE CEREBELLOPONTINE ANGLE PRESENTING AS TRIGEMINAL NEURALGIA
}

\author{
PAULO C. FIGUEIREDO - MARIO BROCK
}

A. MATTOS DE OLIVEIRA JR. - A, PRILL

SUMMARY - A case of arteriovenous malformation of the left cerebellopontine angle causing symptoms of ipsilateral trigeminal neuralgia is reported. Pain relief followed microsurgical removal of the malformation. The authors review the literature on the subject.

Apresentação por nevralgía do trigêmeo de malformação arteriosenosa no angulo pontocerebelar.

RESUMO -- Registro de caso de malformação arteriovenosa no ângulo cerebelopontinu esquerảo que determinava sintomatologia ipsilateral de nevralğia do trigêmeo. A remoçāo microcirúrgica da maiformaça foi seguida de remissão da dor. Os autores revèem a literatura acerca do assunto.

Arteriovenous malformations (AVM) of the posterior fossa are rare. This is particularly true for those located in the cerebellopontine angle in the brain stem. Among these, only a very small proportion causes trigeminal neuralgia, either as initial or as only symptom (Table 1). The successful treatment of such a rarity has prompted an extensive review of the literature and appears to justify this publication.

\section{CASE REPORT}

SH, an 18-year-uld right-handed nan was referred on May 21, 1979 . He had been admitted to another hospital because of trigeminal neuralgia of three months duration, affecting the territory of the ophthalmic branch on the left side. A few days prior tc admission he had started complaining about dizz ness, nausea and vomiting upon motion of his body or head. His gait had become unsteady. At admission the patient was in good general condition. Blood pressure was $110 / 70 \mathrm{mmHg}$, pulse rate, temperature and respiration were normal. There was a horizontal nystagmus on gaze to the left. Romberg's sign was positive without lateralization. The left hand was ataxic, the neck slightly stiff. Auscultation of the head revealed no bruit. The past history comprised learning difficulties at school and occasional generailzed seizures following an episode diagnosed as «meningoencephalitis» at the age of 6 . Brain scintillography and computerized tomography revealed changes compatible with the diagnosis of a lesion in the left cerebellopontine angle. Electronystagmography revealed disturbances in vestibular function on the left. EEG disclosed patholugical putentials compatible with subcortical involvement. Vertebral angiography by transfemoral route showed an AVM arising from the anterior inferior cerebellar artery in the left cerebellopontine angle (Fig. 1).

Neurosurgical Department, University of Berlin, West Germany.

Prof. Dr. med. Mario Brock - Neurochirurgische Klinik, Freie Universitït Berlin - Hindenburgdamm 30 - D-1000 Berlin 45 - West Germany 
Operation - On May 23, 1979, the AVM was approached by suboccipital route with the patient in the sitting position. Following the opening of the cerebello-medullary cystern the lesion was promptly visualized. The supplying vessels were occluded by bipolar coagulation, divided, and the AVM gradually freed from the surface of the cerbellum and pons. Additional smaller fceding vessels were also coagulated and divided. During dissection a huge draining vein, extending upwards along the cerebellar surface, was clipped. Following this, the AVM gradually increased in volume because of the persistence of a small undetected feeding artery. This was also clipped, coagulated and divided, whereafter the lesion shrunk and was renioved in one piece. Postoperative recovery was uneventful. Control angiography (Fig. 2) confirmed the complete removal of the malfunction. Trigeminal pain never recurred. There was only a transient numbness in the territory of the mandibular branch.

\section{COMMENTS}

The incidence of AVMs of the posterior fossa amounts to only about $6 \%$ to $7 \%$ of all intracranial AVMs 31,32. Initial symptoms usually indicate a cerebellar or brain stem disease. Only very rarely does a patient present with trigeninal neuralgia. We were able to find only 18 such cases in the literature (Table 1). Eisenbrey and Hegarty 12 seem to be the first to have specifically described a case of trigeminal neuralgia associated with an AVM in the cerebellopontine angle. No treatment was performed. Olivecrona 35 mentioned a typical case of trigeminal neuralgia caused by an AVM in the cerebellopontine angle. Dereux et al.9 described a case of AVM of the cerebellopontine angle without trigeminal neuralgia submitted only to surgical exploration. The first successful surgical removal of the cerebellopontine angle AVM was probabbly performed by Green and Vaughan (1972)17. More recently, Chou et al.5, Drake 10, Matsumura et al.31, and Solomon and Stein 51 described excellent surgical results.

Table 1 summarizes the cases reported in literature. Among the 18 cases of AVM in the cerebellopontine angle associated with trigeminal neuralgia, facial pain was the initial symptom in 12 . In 7 of the 18 cases the left cerebellopontine angle was involved. The incidence was practically the same for both sexes. Almost all arteries of the posterior fossa may serve as feeding vessels for the AVMs of the cerebellopontine angle. The most commonly encountered feeding vessel is the AICA. Serial angiography remains the method of choice for studying AVMs of the posterior fossa and for demonstrating the effectiveness of surgical therapy. A case of spontaneous (angiographic) disáppearance and reappearance of an AVM of the cerebellum and brain stem has also been recorded 38 .

The natural history of AVMs of the posterior fossa is unclear. However, recent technical achievements support the view that total extirpation is the best treatment also for AVMs in this location. In cases of trigeminal neuralgia due to AVM in the cerebellopontine angle complete removal is curative. It remains a matter of speculation whether in such cases trigeminal neuralgia results from neurovascular compression or is due to ischemia of the trigeminal nucleus or root.

We extirpated the AVM by suboccipital route. In the cases in which the malformation is located on the rostral and ventral aspect of the cerebellum, Matsumura et al.31 and Verbiest 55 recommend a suboccipital transtentorial approach. The view that excision of AVMs in the cerebellopontine angle and the brain stem is impossible or exceedingly dangerous can no longer be held. 


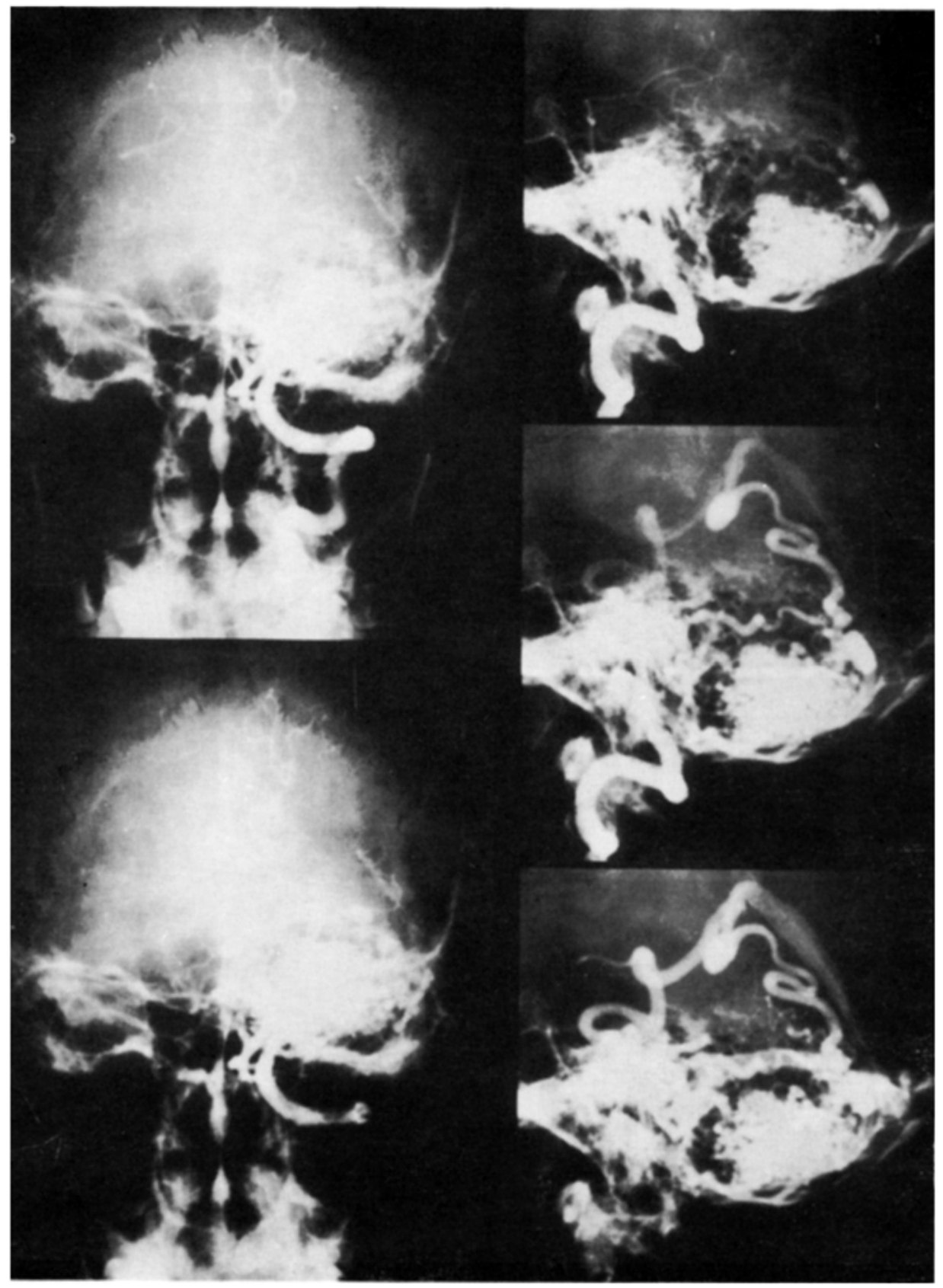

Fig. 1 - Preoperative vertebral and right carotid angiogram showiny the arterial supply and venous drainige of the malformation. 

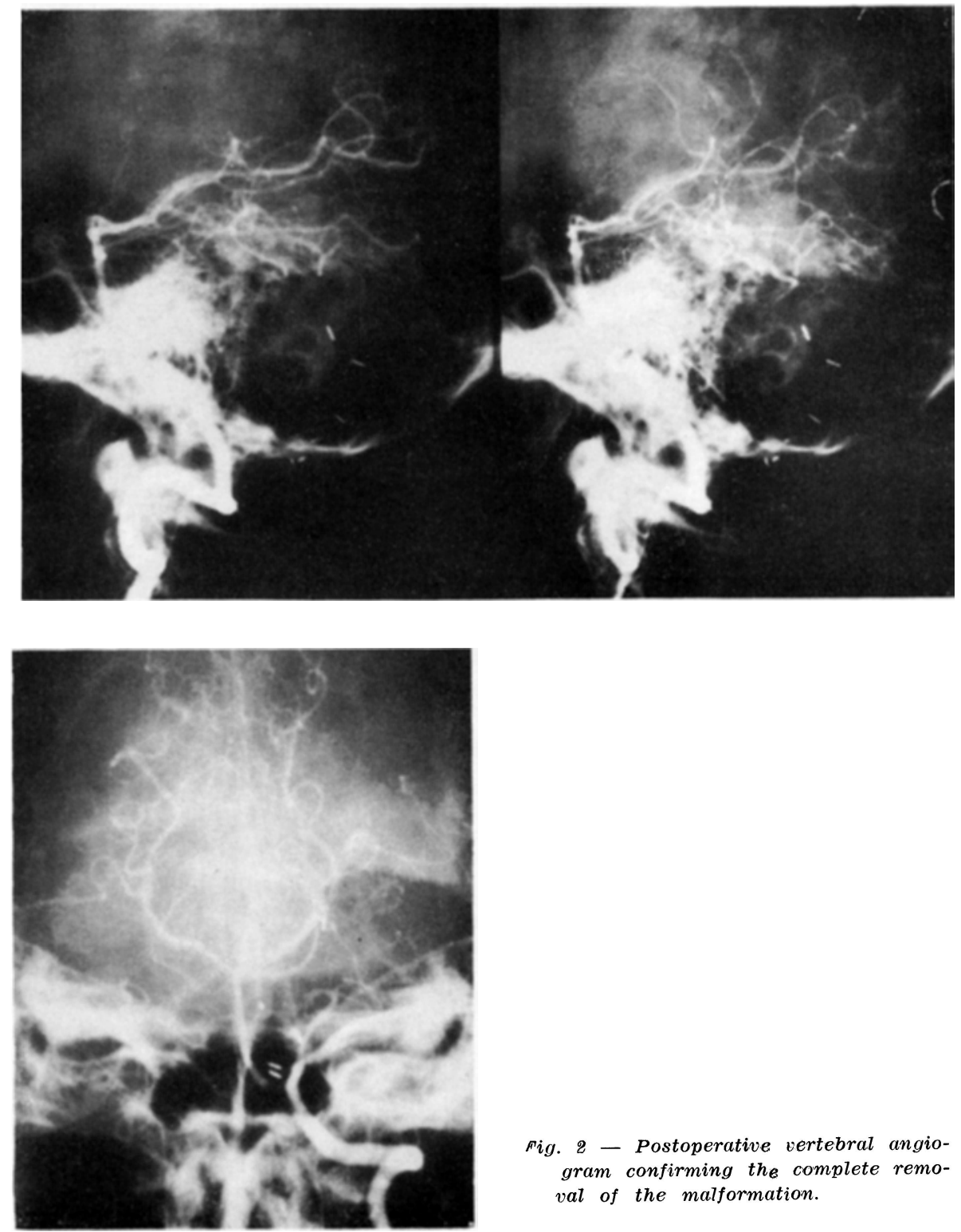

Fig. 2 - Postoperative vertebral angiogram confirming the complete removal of the malformation. 


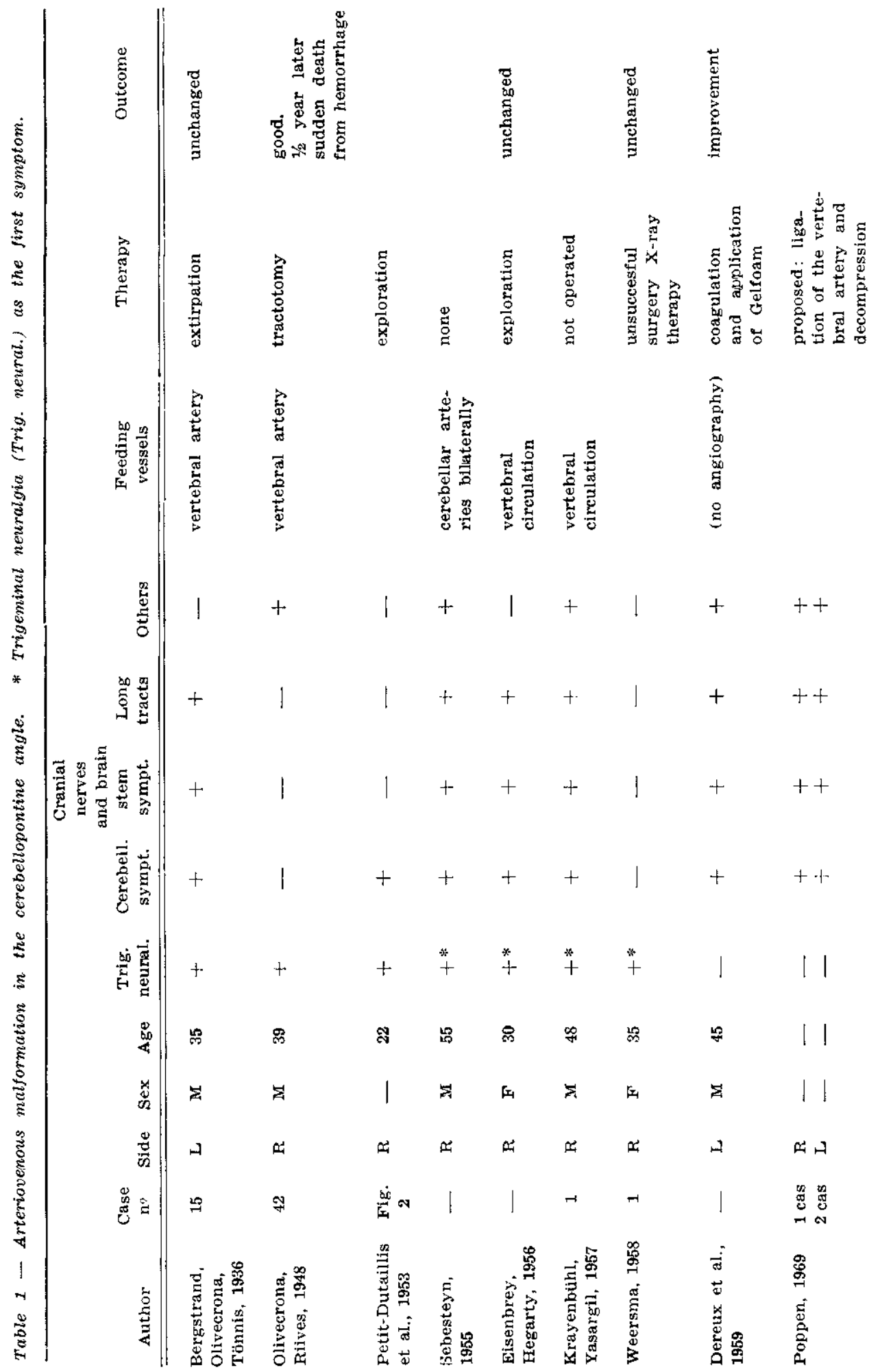




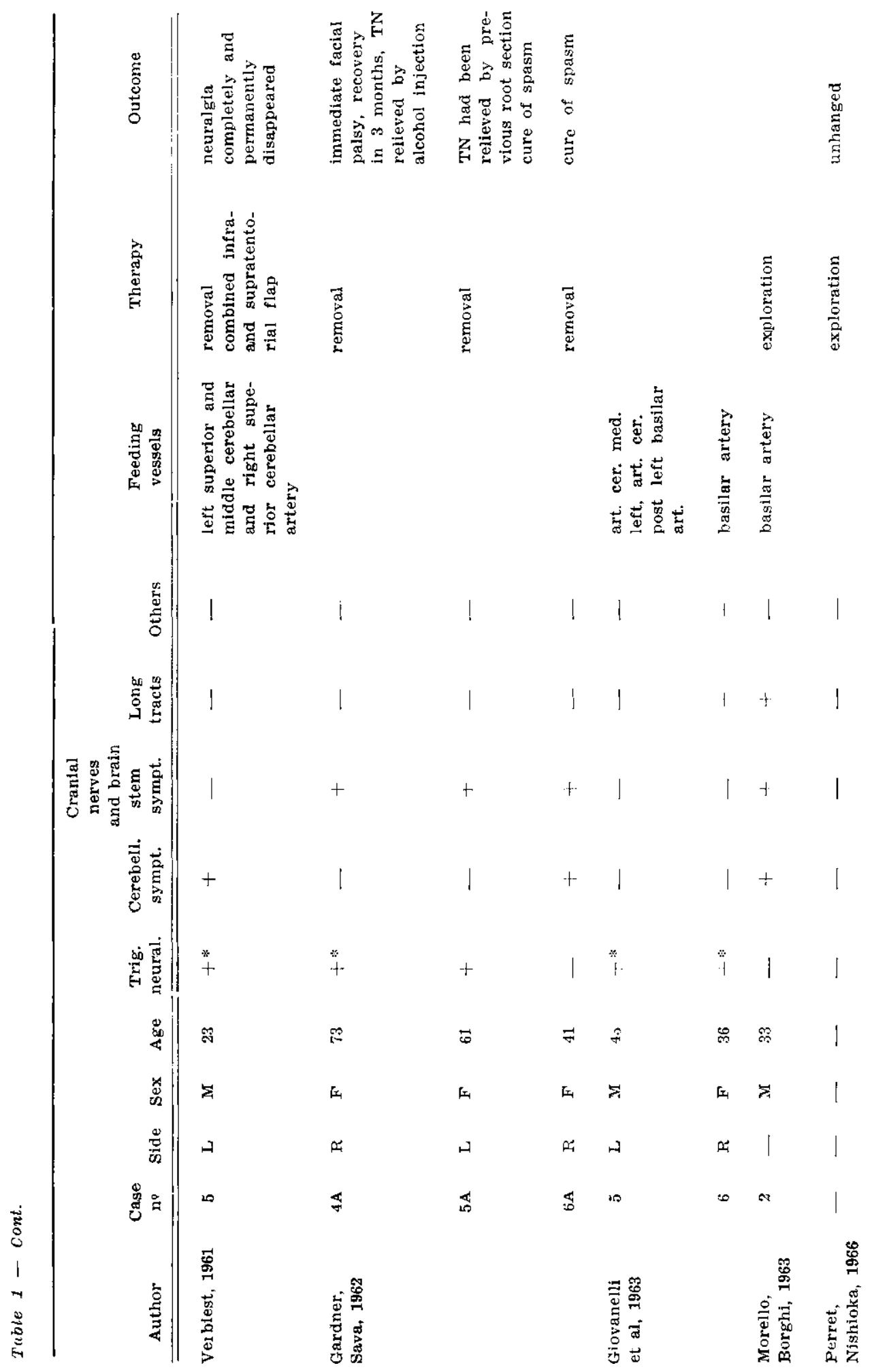




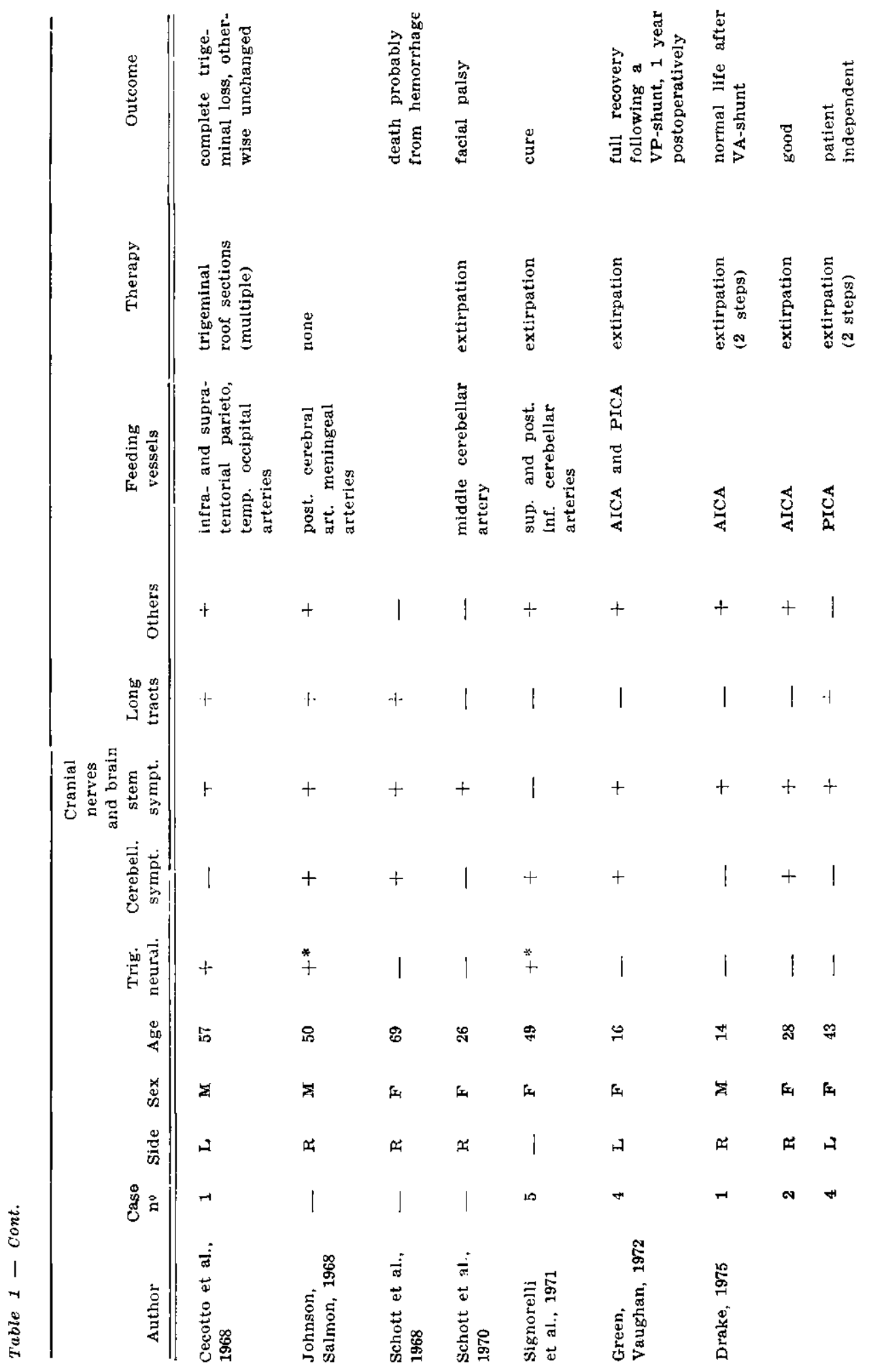




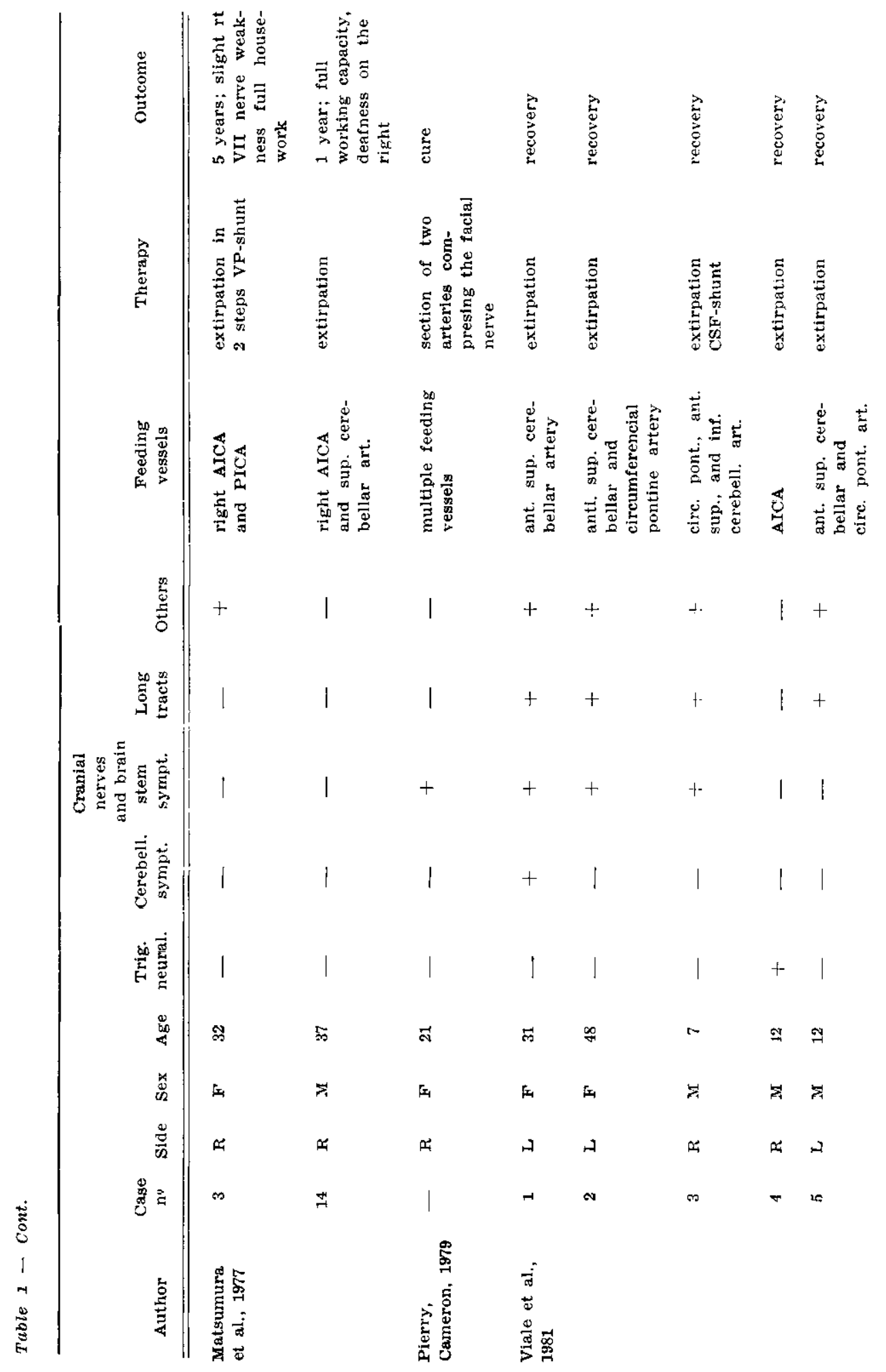




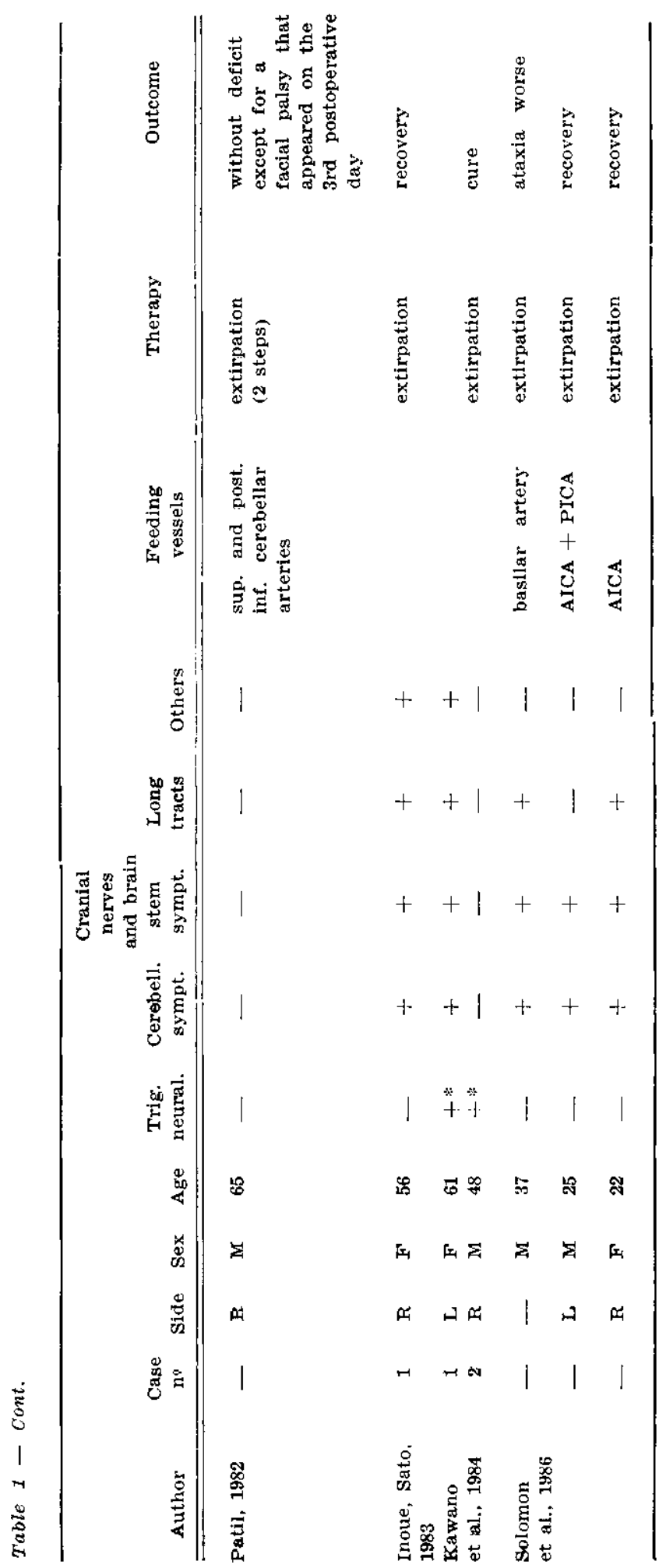




\section{REFERENCES}

1. Baird WF, Stitt DG - Arteriovenous aneurysm of the cerebellum in a premature infant. Pediat 24:455, 1959.

2. Bergstrand H, Olivercrona H, Tönnis $W-$ Gefässmissbildungen und Gefässgeschwiłlste des Gehirns. Georg Thieme, Leipzig, 1936, VI, pg 181.

3. Bertrand MA, Molina $P$, Hardy $J$ - Vestibular syndrome and vascular anomaly in the cerebellopontine angle. Acta Otolaryngol 83:187, 1977.

4. Cecotto C, Zotti G, Shiavi F - Nevralgia trigeminale essenziale come sintomo di anomalia vascolare congenita endocranica. Minerva Med 5:213, 1968.

5. Chou SN, Erickson DL, Ortiz-Suarez HJ - Surgical treatment of vascular lesions in the brain stem. J Neurosurg $42: 23$, 1975.

6. Ciminello VJ, Sachs EJr - Arteriovenous malformation of the posterior fossa. J Neurosurg 19:602-604, 1962 .

7. Delman M - Posterior fossa arteriovenous malformation. Am J Ophthalm 56:409, 1963.

8. Dereux J, Dereymaeker A, Delberghe $P$, Degerdt $R$ - Aneurysme artério-veineux de la fosse postérieure (angle pontocerebelleux). Rev Neurol 100:56, 1959.

9. Dereux J, Nayrac P, Laine E, Galibert P, Delandtsheer JM, Pruvot P, Rief G, Debert R - Neuf aneurysmes artério-veineux de la fosse postérieure. Neuro-Chirurgie 5: 257, 1959.

10. Drake CG - Surgicel removal of arteriovenous malformation from the brain stem and cerebellopontine angle. J Neurosurg 43:661, 1975.

11. Dujovny H, Osgood CP, Failie R, Bennett MH, Kerber C - Posterior fossa AVM producing hemifacial spasm. Angiology 3:425, 1979.

12. Eisenbrey AB, Hegarty WM - Trigeminal neuralgia and arteriovenous aneurysm of the cerebellopontine angle. J Neurosurg 13:647, 1956.

13. Fabinyi GCA, Adams CBT - Hemifacial spasm: treatment by posterior fossa surgery. J Neurol Neurosurg Psychiat 41:829, 1978.

14. Gardner WJ, Sava GA - Hemifacial spasm: a reversible pathophysiologic state. J Neurosurg $19: 240,1962$.

15. Giovanelli $M$, Marini $G$, Harossero $F$ - Nevralgia trigeminale tipica in presenza di lesioni organiche macroscipiche del sistema nevrosa centrale. Minerva Neurochir 7: $124,1963$.

16. Graf CJ, Menezes AH - Arteriovenous malformation in the posterior fossa supplied by the external carotid circulation. J Neurosurg 41:502, 1974.

17. Green JR, Vaughan J - Blood vessel tumors and hematomas of the posterior fossa in adolescence. Angiology 23:474, 1972.

18. Grotts BF - Spontaneous hemorrhage from hemangioma of the pons. $j$ Pediat 37:98, 1950.

19. Hoare RD - Arteriovenous aneurysm of the posterior fossa. Acta Radiol 4:96, 1953.

20. Inoue $Y$, Sato $O-$ Successfui removal of pontine hematoma due to rupture of cryptic AVM. Acta Neurochir 69:69, 1983.

21. Janetta PJ, Abbasy H, Maroon JC, Ramos FH, Albin MS - Etiology and definitive microsurgical treatment of hemifacial spasm: operative techniques and results in 17 patients. J Neurosurg 47:321, 1977.

22. Johnson MC, Salmon $\mathrm{JH}$ - Arteriovenous malformation presenting as trigeminal neuralgia: case report. J Neurosurg 29:287, 1968.

23. Kasantikul V, Metsky MG - Combined neurilemmoma and angioma: tumor of ectomesenchyme and a source of bleeding. J Neurosurg 50:81, 1979.

21. Kommninoth R. Woringer $\mathbf{E}-$ Nevralgie du trijumeau liée a des malformations anatomiques. Neurochirurgie 10:110, 1964.

25. Krayenbühl H, Ysargil MG - Die vaskulören Erkrankungen im Gebiet der Arteria vertebralis und Arteria basilaris. Georg Thieme, Stuttgart, 1957, pg 136.

26. Laine E, Galibert P - Aneurysmes artério-veineux et cirsoides de la fosse postérieure: à propos de quarante observations. Rev Neurol 115:276, 1967.

27. Laine $\mathbf{E}$, Galibert P, Lopez C, Delahousse J, Delandtsheer JH, Christiagens JL -Aneurysmes artério-veineux intraduraux (developpés dans l'épaisseur de la dure-mère) ảe Ia fosse postérieure. Neuro-chirurgie $9: 147,1963$.

28. Licandro AM, Pellegrini A - Angiomi in fossa cranica posteriore ad corso cronico: aspetti clinici Riv Pat Terv Ment 96:11, 1975.

29. Logue V, Monckton G - Posterior fossa angiomas: a clinic presentation of nine cases. Brain $77: 252,1961$.

30. Marchal JC, Auque J, Hepner H, Roland J, Picard L, Gehin P, Lepoire J - Angiomes caverneux de la fosse postérieure (à propos de 2 observations). Neuro-Chirurgie 1: 57. 1982. 
31. Matsumara H, Makita $\mathbf{Y}$, Someda $\mathbf{K}$, Kondo A - Arteriovenous nalformation in llie posterior fossa. J Neurosurg 47:50, 1977.

32. McCormick Wr. Hardman JH. Boulter TR - Vasculur malformations («angiomas») of the brain, with special reference to those occurring in the posterior fossa. J Neurosurg $28: 241,1968$.

33. Morello G, Borghi GP - Les angiomes sous-tentoriels: contribution clinique. NeuroChirurgie $9: 446,1963$.

34. Mount LA - Arteriovenous angjoma derived from the anterior inferior cerebellar artery: its diagnosis and treatment. J Neurosurg 22:612, 1965.

35. Olivecrona $\mathrm{H}$ - Cholesteatomas of the cerebello-pontine angle. Acta Psychiat Neurol $24: 634,1949$.

36. Olivecrona H, Rives $\mathbf{J}$-- Arteriovenous aneurysms oi the brain: their diagnosis and treaiment. Arch Neurol Psychiat 59:567, 1948.

37. Patil Af - Surgical excision of arteriovenous malformation of the cercbellum and brain stem. Acta Neurochir (Wien) $54: 117,1980$.

38. Patil AA - Angiographic disappearance and reappearance of an arteriovenous malformation of the cerebellum and the brain stem, and its surgical excision. Acta Neurochir $52: 247,1982$.

39. Forret $G$, Nishioka $H$ - Report on the cooperative study on intracranial aneurysms and subarachnoid hemorrhage: section V. J Neurosurg 25:46/, 1966.

40. Pet.t-Dutaillis D, Messimy R, Berdet H, Maralton A - sur un cas d'hemangiome du tronc cerebral. Rev Neurol 102:92, 1960.

41. Petit-Dutaillis D, Pertuiset B, Rougerie J, Namin $\mathbf{P}$ - Indications et resultats de l'angiographie vertebrale en neurochirurgie. Presse Med 61:1499, 1953.

42. Pjerry A, Cameron $M$ - Chronic nemifacial spusm from posterior fossa arteriuvenous malformation. J Neurol Neurosurg Psycniat 42:670, 1979.

43. Poppen JL - Vascular surgery of the posterior fossa. Clin Neurosurg 6:198, 1969.

44. Rondot $P$ - Affections neurologiques pseudotunorales de l'adult localisées aux étages moyens et postérieurs de la base du crâne. Ann Oto-Laryng 98:201, 1981.

45. Russo RH, Dicks RE - Arteriovenous malformation of the brain stem in childhood. Sure Neurol 8:167, 1977.

16. Schultz EC. Huston WA - Arteriovenous aneurysm of the posterior fossa in an infant: report of a case. I Neurosurg 13:211, 1956.

47. Sebestyen M - Demonstration eines Failes mit Hemangiom im Bereiche der A. vertebraliss. Wien Zschr Nervenk 12:137, 1955.

48. Signorelli CD, Tedeschi G, Uratino A - Malformazicni artero-venose della fossa cranica posteriore. Rass Int Clin 50:1389, 1971.

49. Shott B, Garde A, Tommasi M, Bady M, Michel D, Rochet H - Malformation vasculaire de l'angle ponto-cerébelleux. Kev Neurol 118:222, 1968 .

50. Shott B, Morgan A, Bady B, Berrard PA - Cavernome de l'angle ponto-cérébelleux. $J$ Franç d'oto-knino-Laryngol $4: 289,1970$.

51. Solomon RT, Stein BWI - Management of arteriovenous malformation of the brain stem. $J$ Neurosurg 64:857, 1986.

52. Szdzuy D, Siedschlag WD, Lehmann R, Serfling HJ - Durch arterielle Spasmen maskiertes arteriovenöses Angiom der hinteren Schädelgrube. Zbl Neurochir 36:109, 1975.

53. Tamaki M, Fujita $\mathbf{K}$. Yamashita $\mathbf{H}-$ Multiple arteriovenous malformation involving the scalp, dura, retina, cerebrum and posterior fossa. J Neurosurg 34:95, 1971.

54. Teadsdal RD - Posterior Lossa arteriovenous aneurysm with occlusion of a vertebral artery. Neurology $8: 571,1958$.

55. Verbiest $H$ - Arteriovenous aneurysm of the posterior fossa: analysis of six cases. Acta Neurochir 9:171, 1961.

56. Viale GL, Pau A, Viale ES - Surgical treatment of arteriovenous malformations of the posterior fossa. Surg Neurol 12:379, 1979.

57. Viale GL, Pau A, Viale ES, Turtas $\mathrm{S} \longrightarrow$ Angiomas of the cerebellopontine angle. $J$ Neurol 225:259, 1981.

58. Walter W, Schetller G, Bischof W - Klinik und Therapie der arteriovenösen Angiome im Bereich der hinteren Schädelgruppe. Dtsch Z Nervenk 191:39, 1967.

59. Weersma M - Trigeminal neuralgia and arteriovenous aneurysm of the posterior fossa. Fol Psychiat Neurol Neurochir Neerl $3 \cdot 315.1957$. 